\title{
ANALISIS FAKTOR-FAKTOR YANG MEMENGARUHI PROFITABILITAS BANK PEMBIAYAAN RAKYAT SYARIAH DI INDONESIA
}

\section{ANALYSIS OF FACTORS AFFECTING THE PROFITABILITY OF THE ISLAMIC BANK FINANCING IN INDONESIA}

\author{
Ahmad Muhaemin ${ }^{1 a}$ Ranti Wiliasih ${ }^{2 b}$ \\ 1aJurusan Ekonomi SyariahDepartemen Ilmu Ekonomi Institut Pertanian \\ Bogor, Jl. Raya Darmaga Kampus IPB Darmaga Bogor 16680 \\ 2bJurusan Ekonomi Syariah Departemen Ilmu Ekonomi Institut Pertanian \\ Bogor, Jl. Raya Darmaga Kampus IPB Darmaga Bogor 16680
}

(DiterimaolehDewanRedaksi: 18-01-2016)

(Dipublikasikan oleh Dewan Redaksi: 01-06-2016)

\begin{abstract}
Profitability is one of the indicators to measure the performance of financial institutions, including Islamic Rural Banks, Islamic bankswhich focus in providing microfinance. The purpose of this study was to analyze the factors those affect the profitability of Islamic Rural Banks in Indonesia. This study used date monthly date from January 2013 until December 2015 with analytical method isOrdinary Least Square(OLS). The result of this study indicated that Capital Adequacy Ratio (CAR) and Financing to Deposit Ratio (FDR) have positive relationshipeffect (significant) to the profitability of Islamic Rural Banks.Non Peforming Financing (NPF), Operational Efficiency Ratio (OER), and inflation have negative relationshipeffect (significant)to the profitability of Islamic Rural Banks, while BI rate hasa negative relationship effect (not significant) on the profitability of Islamic Rural Banks in Indonesia.
\end{abstract}

Keywords: BPRS, OLS, profitability

\begin{abstract}
ABSTRAK
Profitabilitas merupakan salah satu indikator untuk mengukur kinerja lembaga keuangan, termasuk BPRS Bank, fokus bankswhich Islam dalam menyediakan keuangan mikro. Tujuan dari penelitian ini adalah untuk menganalisis faktor-faktor yang mempengaruhi profitabilitas BPR Islam di Indonesia. Penelitian ini menggunakan tanggal tanggal bulanan dari Januari 2013 sampai dengan Desember 2015 dengan metode analisis isOrdinary Least Square (OLS). Hasil penelitian ini menunjukkan bahwa Capital Adequacy Ratio (CAR) dan Financing to Deposit Ratio (FDR) memiliki relationshipeffect positif (signifikan) terhadap profitabilitas Islam Rural Banks.Non peforming Financing (NPF), Operasional Efficiency Ratio (OER),
\end{abstract}


dan inflasi memiliki relationshipeffect negatif (signifikan) terhadap profitabilitas BPR Islam, sementara BI rate hasa efek hubungan negatif (tidak signifikan) terhadap profitabilitas Bank Perkreditan Rakyat Islam di Indonesia.

Ahmad Muhaemin. 2015. Analisis Faktor-Faktor Yang Memengaruhi Profitabilitas Bank Pembiayaan Rakyat Syariah Di Indonesia (4): 181-207

\section{PENDAHULUAN}

Bank merupakan lembaga keuangan yang berpengaruh dalam perekonomian suatu negara baik secara mikro maupun secara makro. Bank memiliki fungsi sebagai perantara keuangan (financial intermediary) antara pihak-pihak yang surplus dengan pihak-pihak yang membutuhkan dana atau defisit. Dalam menjalankan aktivitas usahanya sebagai lembaga keuangan yang menjual kepercayaan dan jasa, setiap bank akan berusaha menarik nasabah barusebanyak mungkin, menghimpun dana dari masyarakat dan juga memperbesar komposisi kredit yang diberikan kepada nasabah (Firmansyah 2014).

Disahkannya Undang-Undang Nomor 10 tahun 1998 perubahan atas Undang-Undang Nomor 7 tahun 1992 tentang Perbankan mengenai dual banking system, telah memberikan peluang bagi tumbuhnya industri perbankan syariah dan memberikan kesempatan yang luas kepada bank umum untuk membuka kantor cabang yang khusus melakukan kegiatan usaha berdasarkan prinsip syariah atau bahkan mengkonversi diri secara total menjadi bank syariah.

Menurut data Otoritas Jasa Keuangan (2015), perbankan syariah di Indonesia telah mengalami perkembangan baik dalam hal kelembagaan ataupun kepemilikan aset. Sampai dengan Desember 2015, telah tercatat 12 Bank Umum Syariah (BUS), 22 Unit Usaha Syariah (UUS) dan 163 Bank Pembiayaan Rakyat Syariah (BPRS) yang tersebar di wilayah Indonesia. Selain itu, total aset yang dimiliki oleh perbankan syariah pada tahun 2015 mencapai Rp303.99 Triliun. Jumlah tersebut mengalami peningkatan sebesar 8 persen dari tahun 2014 .

Bank Pembiayaan Rakyat Syariah (BPRS) adalah salah satu bentuk perbankan syariah yang melaksanakan fungsi intermediasi dengan menyalurkan pembiayaan kepada masyarakat. BPRS didirikan dengan tujuan membantu permodalan unit usaha mikro, kecil danmenengah (UMKM). Tujuan tersebut direalisasi dalam bentuk pembiayaan yang disalurkan ke lapangan usaha yang termasuk dalam golongan pembiayaan UMKM (Adawiyah 2016). BPRS beroperasi pada daerah yang masih membutuhkan pembiayaan, selain menghindari persaingan dengan bank-bank umum juga membuka akses untuk masyarakat yang belum bankable. BPRS beroperasi pada daerah pedesaan/kabupaten,di daerahdaerah yang membutuhkan pembiayaan sehingga BPRS 
mempunyai jangkauan yang lebih luas di masyarakat.

Bank Pembiayaan Rakyat Syariah (BPRS) sebagai bagian dari perbankan syariah memiliki fokus melakukan kegiatan pada operasi sektor riil sehingga memiliki sifat yang berpengaruh besar dalam perubahan kondisi makro ekonomi (Afifah 2014). Hal tersebut akan mendorong pihak manajemen BPRS untuk melakukan berbagai usaha dan strategi guna mendukung tercapainya tingkat kesehatan perbankan yang optimal.

Bank Pembiayaan Rakyat Syariah (BPRS) senantiasa mengalami perkembangan yang berfluktuasi baik dari kepemilikan aset ataupun kinerja (OJK 2015). BPRS mengalami pertumbuhan yang sangat besar dari segi kepemilikan aset. Pada akhir tahun 2015, total aset yang dimiliki oleh BPRS mencapai Rp7.7 Triliun, jumlah tersebut mengalami peningkatan sebesar 17 persen dari tahun 2014. Namun, peningkatan total aset BPRS tidak diikuti dengan peningkatan kinerja. Kinerja BPRS yang diproksikan oleh rasio profitabilitas pada akhir tahun 2015 mencapai nilai yaitu 2.2 persen, nilai tersebut mengalami penurunan sebesar 0.05 persen dari tahun 2014 dan 0.5 persen dari tahun 2013.

Profitabilitas merupakan indikator yang tepat untuk mengukur kinerja dan kemampuan bersaing suatu bank (Harahap 2006). Salah satu indikator yang digunakan untuk mengukur tingkat profitabilitas adalah melalui Return on Asset (ROA) atau rasio laba terhadap aset. Menurut Wibowo dan Syaichu (2013), ROA digunakan untuk mengukur profitabilitas bank karena Bank Indonesia sebagai pembina dan pengawas perbankan lebih mengutamakan nilai profitabilitas yang diukur dari aset yang dananya berasal dari sebagian besar dana simpanan masyarakat. Selain itu, BPRS sendiri lebih fokus melakukan kegiatan yang berhubungan pada operasi sektor riil. ROA merupakan indikator yang tepat untuk mengukur profitabilitas dari BPRS.

Haron (2004) menyatakan bahwa terdapat dua kategori yang dapat memengaruhi profitabilitas suatu bank. Kategori pertama adalah faktor internal yang berkaitan dengan pengelolaan manajemen bank. Semakin tinggi profitabilitas suatu bank maka semakin baik pula kinerja bank tersebut. Kategori kedua adalah faktor eksternal dimana faktor ini di luar kendali pihak manajemen bank, seperti kondisi makroekonomi meliputi Inflasi dan volatilitas tingkat suku bunga (Siamat 2005).

Usaha mikro, kecil dan menengah (UMKM) memiliki peranan penting dalam pembangunan perekonomian khususnya pembangunan sektor riil. Hal tersebut ditunjukan dengan kontribusi sektor UMKM terhadap penyerapan tenaga kerja nasionalyang mencapai 107.6 juta pekerja atau sekitar 97 persen dari jumlah pekerja di Indonesia (BPS 2012). Namun, sektor UMKM di Indonesia dalam perkembanganya mempunyai beberapa kendala 
yang salah satunya adalah aspek pembiayaan.

Salah satu lembaga keuangan yang dapat meningkatkan perkembangan UMKM adalah Bank Pembiayaan Rakyat Syariah (BPRS). Kontribusi BPRS terhadap perkembangan UMKM ditunjukan dengan proporsi jumlah pembiayaan oleh BPRS kepada UMKM yang mencpai Rp3.37 Triliun di tahun 2015 (OJK 2015). Semangat BPRS untuk peduli kepada UMKM didorong oleh pengamalan firman Allah SWT dalam Q.S. Al-Hasyr ayat 7 berikut:

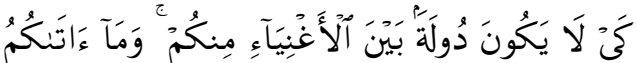

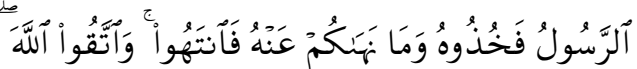

$$
\begin{aligned}
& \text { إِنَّ الْلَّهَ شَدِيدُ آلَْعِقَابِ }
\end{aligned}
$$

Artinya :"....supaya harta itu jangan beredar di antara orang-orang Kaya saja di antara kamu..."(QS. AlHasyr: 7).

Namun, peranan penting yang dimiliki oleh BPRS nyatanya masih belum diimbangi dengan komposisi total aset. Data Statistik Perbankan Syariah pada bulan Desember 2015 menjelaskan bahwa total aset seluruh Bank Pembiayaan Rakyat Syariah
(BPRS) hanya 2.5 pesen dari keseluruhan total aset perbankan syariah Indonesia yang telah mencapai Rp. 303.99Triliun. Total aset BPRS tersebut tentunya masih rendah jika dibandingkan dengan keseluruhan total aset perbankan syariah nasional.

Dilihat dari aspek keuntungan, profitabilitas merupakan indikator yang menggambarkan kinerja BPRS. Profitabilitas BPRS di Indonesia mengalami tren sepanjang periode 2011 sampai 2015. Pada tahun 2013 profitabilitas BPRS mencapai nilai tertinggi yaitu 3.1 persen. Namun, pada tahun 2015, profitabilitas BPRS mencapai nilai terkecil yaitu 2.07 persen.Penurunan profitabilitas BPRSdipengaruhi oleh faktor internal dan eksternal. Faktor internal berkaitan dengan manajemen BPRS atau pola alokasi sumber daya yang memungkinkan BPRS dapat mempertahankan kinerjanya. Faktor eksternal berkaitan dengan kondisi yang berada di luar kendali pihak manajemen BPRS, seperti makroekonomi yang salah satunya adalah inflasi.

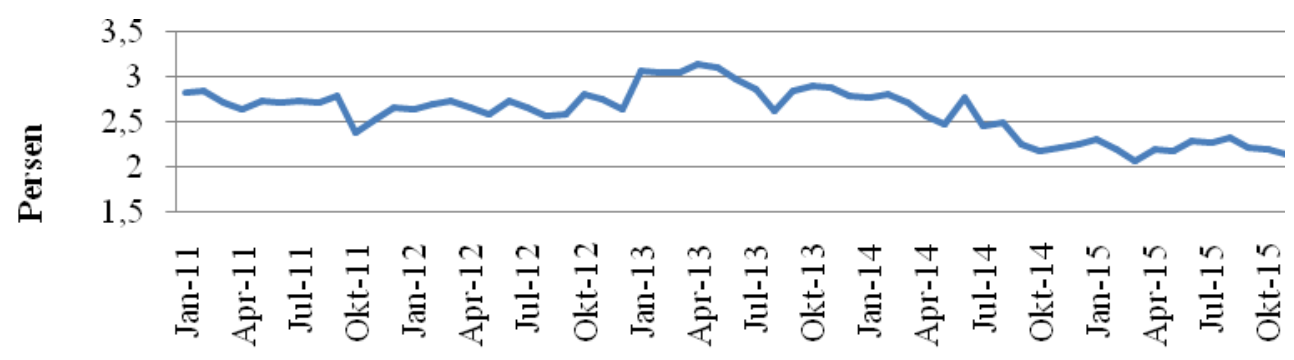

Periode

Sumber : Statistik Perbankan Syariah, OJK 2015

Gambar 1 TrenProfitabilitas BPRS di Indonesia tahun 2011-2015 
Penelitian terdahulu yang dilakukan oleh Afifah (2014), tentang profitabilitas menunjukan bahwa Bank Pembiayaan Rakyat Syariah (BPRS) sebagai bagian dari bank syariah memiliki hubungan erat dengan kondisi makro ekonomi, salah satunya inflasi. Inflasi di Indonesia yangberfluktuasi memberikan dampak negatif terhadap kinerja BPRS. Hal ini dikarenakan pendapatan utama BPRS terfokus pada keuntungan dari pembiayaan yang bergerak pada sektor riil. Naiknya biaya produksi dan biaya operasional yang disebabkan oleh inflasi membuat risiko yang dihadapi BPRS menjadi tinggi.

\section{MATERI DAN METODE}

\section{Bank Pembiayaan Rakyat Syariah}

Bank Pembiayaan Rakyat Syariah(BPRS) adalah bagian dari bank syariah yang memiliki fokus melakukan pembiayaan pada UMKM. BPRS berfungsi sebagai pelaksana sebagian fungsi bank umum di tingkat regional dengan berlandaskan prinsip syariah (Soemitra 2009). Bentuk hukum BPRS adalah perseroan terbatas. Berdasarkan UU No. 21 Tahun 2008 tentang Perbankan Syariah, operasional BPRS meliputi kegiatan menghimpun dana masyarakat dalam bentuk tabungan, deposito, dan atau bentuk lainnya yang dipersamakan dengan itu, menyediakan pembiayaan dan penempatan dana berdasarkan prinsip syariah, menempatkan dananya dalam bentuk Sertifikat Wadiah Bank Indonesia (SWBI), deposito berjangka, sertifikat deposito, dan/atau tabungan pada bank lainnya. BPRS dilarang menerima simpanan berupa giro dan ikut serta dalam lalu lintas pembayaran, melakukan kegiatan usaha dalam valuta asing, melakukan penyertaan modal, dan melakukan usaha perasuransian.

Kegiatan penyaluran dana dari BPRS kepada masyarakat dilakukan dalambentuk pembiayaan berdasarkan prinsip jual beli (murabahah, istishna',salam); prinsip sewa menyewa (ijarah);prinsip bagi hasil (mudharabah, musyarakah);prinsip kebajikan (qardh hasan)(Soemitra 2009).Dalam memberikan pelayanan berupa pembiayaan, BPRS perlu memahami karakteristik calon nasabahnya, apakah nasabahnya baru memulai suatu bisnis atau telah menjalankan bisnis, apakah usahanya sedang tumbuh berkembang, stabil atau tidak stabil, dan apakah sektor usaha dari nasabahnya (pertanian, perdagangan, industri kecil), dan lain sebagainya. Dengan memahami karakteristik nasabahnya, BPRS tersesbut dapat menentukan jenis produk dan jasa keuangan yang tepat sesuai dengan kebutuhan nasabahnya. Kesalahan dalam menawarkan jenis produk dan jasa keuangan dapat menciptakan masalah seperti pembiayaan non lancar.

\section{Konsep Profitabilitas}

1. Definisi Profitabilitas

Profitabilitas merupakan kemampuan suatu perusahaan untuk mendapatkan laba 
(keuntungan) dalam suatu periode tertentu. Laba adalah penerimaan yang diperoleh setelah membayar biaya produksi. Perolehan laba yang diperoleh merupakan gambaran kinerja perusahaan dalam menjalankan kegiatan usahanya. Profitabilitas juga dapat digunakan sebagai evaluasi efisiensi pengelolaan perusahan tersebut, karena efisiensi baru dapat diketahui dengan membandingkan laba yang diperoleh dengan aktiva yang digunakan untuk menghasilkan laba tersebut.

Bank syariah memperoleh laba dalam bentuk bagi hasil (profit sharing) dengan nasabah atas pembiayaan yang diberikan dan atau pemberian imbalan atas dana masyarakat.Profitabilitas menjadi hal yang penting bagi bank. Semakin tinggi profitabilitas suatu bank menunjukkan semakin baik dan efisien kinerja bank tersebut. Untuk menilai profitabilitas suatu perusahaan diperlukan berbagai alat analisis, tergantung dari tujuan analisisnya. Alat analisis tersebut adalah rasio profitabilitas. Jenis-jenis rasio profitabilitas yang dapat digunakan yaitu profit margin, Return on Asset (ROA), Return on Equity (ROE), rasio biaya operasional serta Net Interest Margin (NIM).

2. Return on Asset (ROA)

ROA merupakan alat analisis yang sering digunakan untuk menganilisis profitabilitas. Menurut Dendawijaya (2005), ROA digunakan untuk mengukur kemampuan manajemen bank dalam memperoleh keuntungan (laba) secara keseluruhan dari pengelolaan aset yang dimiliki. Semakin besar ROA suatu bank, semakin besar pula tingkat keuntungan yang dicapai bank tersebut dan semakin baik pula posisi bank tersebut dari segi penggunaan aset.

ROA memberikan informasi mengenai seberapa efisien suatu bank dalammenjalankan kegiatan usahanya, karena rasio ini mengindikasikan seberapa besar keuntungan yang dapat diperoleh rata-rata terhadap setiap rupiah asetnya (Siamat2005). ROA dapat diukur dengan perbandingan antara laba sebelum pajak terhadap total aset (total aktiva).Pengukuran kinerja keuangan perusahaan dengan ROA memiliki keuntungan yaitu ROA sangat mudah dihitung dan dipahami. ROA juga merupakan denominator yang dapat diterapkan pada setiap unit organisasi yang bertanggung jawab terhadap profitabilitas dan unit usaha. ROA digunakan sebagai variabel dependen dalam penelitian ini karena ROA mengukur efektifitas perusahaan di dalam menghasilkan keuntungan dengan memanfaatkan aktiva yang dimilikinya. Adapun rumus yang dapat digunakan untuk mengukur ROA adalah sebagai berikut:

$$
\text { ROA }=\frac{\text { Laba Sebelum Pajak }}{\text { Total Aktiva }} \times 100 \%
$$


Berdasarkan Surat Edaran BI No9/29/DPbS tahun 2007 tentang Penilaian Tingkat Kesehatan Bank Perkreditan Rakyat Berdasarkan Prinsip
Syariah, Klasifikasi tingkat ROA secara rinci adalah sebagai berikut:

\section{Tabel 1 Matriks Kriteria Peringkat Komponen ROA}

\begin{tabular}{ll}
\hline \hline Rasio $(\%)$ & Peringkat \\
\hline ROA $>1.450$ & Sangat sehat \\
$1.215<$ ROA $\leq 1.450$ & Sehat \\
$0.999<$ ROA $\leq 1.215$ & Cukup sehat \\
$0.765<$ ROA $\leq 0.999$ & Kurang sehat \\
ROA $\leq 0.765$ & Tidak sehat \\
\hline \hline
\end{tabular}

Sumber: SE BI No9/29/DPbS tahun 2007

3. Profit dalam Prespektif Islam Menurut Rosly (2005), bank syariah didirikan untuk menyediakan tempat mobilisasi deposito dan memperluas pembiayaan. Sampai batas tertentu, perusahaan bisnis keuangan Islam atau bank syariah beroperasi atas dasar untuk memaksimalkan keuntungan. Hal ini diupayakan dengan memperhatikan prinsipprinsip syariah, salah satunya adalah dengan larangan menggunakan bunga yang dikenal sabagai riba dalam Islam. Dengan demikian, maksimalisasi keuntungan dalam prespektif Islam akan jauh dari praktik yang tidak etis dan menempatkan bank syariah sebagai bisnis yang mengedepankan moral.

Konsep utama dari perbankan syariah dan pembiayaan adalah dengan larangan menggunakan bunga, namun begitu penerapan perdagangan dan jual beli (albai) dalam aktivitas pembiayaan bank syariah belum mendapat perhatian yang sama seperti halnya bank konvensional yang menggunakan sistem bunga. Hal ini dikarenakan banyak orang berpikir bahwa bank syariah adalah perusahaan perbankan yang beroperasi tanpa bunga. Meskipun hal tersebut benar, secara akurat hal tersebut tidak menggambarkan untuk apa sebenernya bank syariah didirikan.

Bank syariah menjalankan bisnisnya atas dasar prinsipprinsip komersial dan perdagangan (al-bai) dimana keuntungan yang didapat berasal dari implikasi penambahan nilai (kasb) dan pengambilan risiko (ghorm). Rosly (2005) memberikan contoh untuk membuat hal ini jelas dan mencegah kebingungan yang tidak semestinya. Misalnya, ketika orang musyrik di kota Mekkah mengatakanbahwa

perdagangan itu mirip dengan riba, Alquran memberikan penjelasanbahwa Allah SWT menghalalkan jual beli dan melarang ribadalam Q.S. AlBaqarah ayat 275 berikut : 


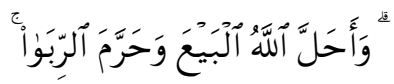

Artinya : "......padahal Allah telah menghalalkan jual beli dan mengharamkan riba....." (Q.S. AlBaqarah : 275)

Jual beli (al-bai) dalam konteks tersebut mengisyaratkan adanya iwad atau timbal balik yang seimbang dalam bertransaksi. Ketika kebutuhan iwad terpenuhi dalam jual beli, maka akan terjadi kesetaraan dan keadilan dalam transaksi bisnis serta menjadikan bank syariah lebih unggul dengan sistem tanpa bunga.

Bunga dilarang dalam Islam karena dianggap sebagai sarana yang tidak dibenarkan dalam pengambilan keuntungan dan penciptaan kekayaan. Pertukaran dari sebuah nilai dengan nilai yang lebih tinggi tidak memerlukan kreditor (peminjam) untuk menanggung risiko pasar dan sistem, mengingat pinjaman dijamin oleh pihak ketiga. Kreditor secara praktis tidak memberikan tambahan kepada debitor. Ini merupakan gambaran umum dalam instrumen pendapatan tetap ( $f i x$ income). Dengan penerapan sistem bunga akan membuat keadilan ekonomi yang berisiko dan kesejahteraan hanya terkonsentrasi di tangan beberapa orang yang dapat mengancam kesejahteraan dan stabilitas sosial.

Perbadaan antara manajemen bank syariah dengan bank konvensional terletak pada pembiayaan dan pemberian balas jasa yang diterima oleh bank dan investor. Balas jasa yang diberikan atau diterima pada bank konvensional berupa bunga dalam persentase pasti sehingga hal ini akan membebani bagi pihak peminjam. Sementara pada bank syariah, pemberian dan penerimaan balas jasa berdasarkan perjanjian (akad). Bank syariah akan memperoleh keuntungan berupa bagi hasiljika menggunakan akad bagi hasil sedangkan jika menggunakan akad jual beli,bank syariah akan memperoleh keuntungan dari margin yang didapatkan.

\section{Rasio Kinerja Perbankan}

1. Capital Adequacy Ratio (CAR)

CAR adalah rasio yang memperlihatkan seberapa jauh seluruh aktiva bank yang mengandung risiko (kredit, penyertaan, surat berharga, tagihan pada bank lain) ikut dibiayai dari dana modal bank sendiri,disamping memperoleh dana-dana dari sumber di luar bank. Dengan kata lain CAR adalah rasio kinerja bank untuk mengukur kecukupan modal yang dimiliki bank untuk menunjang aktiva yang mengandung atau menghasilkan risiko, misalnya pembiayaan (Ismail 2011). Nilai CAR yang tinggi akan memberikan kontribusi yang cukup besar bagi profitabilitas dan mengindikasikan bahwa bank tersebut mempunyai aset yang likuid dalam jangka panjang. Tingginya rasio modal dapat melindungi deposan dan 
meningkatkan kepercayaan masyarakat kepada bank, dan pada akhirnya dapat meningkatkan pendapatan suatu bank.

Perhitungan penyediaan modal minimum (CAR) didasarkan pada prinsip bahwa setiap penanaman dana bank yang mengandung risiko harus disediakan jumlah modal sebesar persentase tertentu dari jumlah penanamannya. CAR dapat dirumuskan sebagai perbandingan antara modal bank terhadap aktiva tertimbang menurut risiko (ATMR). Modal bank adalah total modal yang berasal dari modal inti dan modal pelengkap. Total ATMR merupakan penjumlahan ATMR aktiva neraca dengan ATMR administratif. CAR dihitung dengan menggunakan rumus:

$$
\mathrm{CAR}=\frac{\text { Modat }}{\text { ATMR }} \times 100 \%
$$

Bank Indonesia menetapkan ketentuan modal minimum bagi perbankan sebagaimana ketentuan dalam standar Bank for International Settlemens (BIS) bahwa setiap bank diwajibkan menyediakan modal minimum sebesar 8 persen dari total Aktiva Tertimbang Menurut Risiko (ATMR). Berdasarkan Surat Edaran BI No9/29/DPbS tahun 2007tentang Penilaian Tingkat Kesehatan Bank Perkreditan Rakyat Berdasarkan Prinsip Syariah,klasifikasi tingkat CAR secara rinci adalah sebagai berikut:

Tabel 2 Matriks Kriteria Peringkat Komponen CAR

\begin{tabular}{ll}
\hline Rasio $(\%)$ & Peringkat \\
\hline CAR $\geq 11$ & Sangat sehat \\
$9.5 \leq \mathrm{CAR}<11$ & Sehat \\
$8 \leq \mathrm{CAR}<9.5$ & Cukup sehat \\
$6.5<\mathrm{CAR}<8$ & Kurang sehat \\
$\mathrm{CAR} \leq 6.5$ & Tidak sehat \\
\hline \hline
\end{tabular}

Sumber: SE BI No9/29/DPbS tahun 2007

2. Financing to Deposit Ratio (FDR) Pendeknya waktu antara penarikan dan penyetoran oleh nasabah dapat menyebabkan masalah likuiditas pada bank. Kriteria yang digunakan untuk mengukur likuiditas bank adalah Financing to Deposit Ratio (FDR). Menurut Ismail (2011), FDR merupakan rasio antara seluruh jumlah kredit yang diberikan bank dengan dana yang diterima oleh bank. Rasio ini menyatakan kemampuan bank dalam membayar kembali penarikan dana yang dilakukan deposan dengan mengandalkan pembiayaan yang diberikan sebagai sumber likuiditasnya. Dengan kata lain, seberapa jauh pemberian pembiayaan kepada nasabah dapat mengimbangi kewajiban bank untuk segera memenuhi permintaan deposan yang hendak menarik kembali dananya yang telah disalurkan oleh bank berupa pembiayaan. Semakin tinggi nilai FDR suatu bank, mengindikasikan bahwa 
dana yang disalurkan kepada masyarakat lebih besar daripada dana yang berhasil dihimpun dari pihak ketiga. Disatu sisi FDR yang tinggi menunjukkan bahwa bank tersebut produktif dan fungsi sebagai lembaga intermediasi berjalan dengan baik. Tetapi disisi lain, FDR yang terlalu tinggi menunjukkan likuiditas yang rendah. Hal ini disebabkan jumlah dana yang diperlukan untuk membiayai kredit menjadi besar sehingga ketersediaan dana cadangan untuk menutupi permintaan dana jika nasabah ingin menarik simpanannya menjadi berkurang.. Besarnya jumlah pembiayaan yang disalurkan akan menentukan keuntungan bank. FDR yang tinggi akan meningkatkan laba perusahaan dengan asumsi bank tersebut mampu menyalurkan pembiayaan dengan efektif, sehingga jumlah pembiayaan macetnya akan kecil. FDR dapat diukur dari perbandingan antara seluruh jumlah pembiayaan yang diberikan terhadap dana pihak ketiga. FDR dihitung dengan menggunakan rumus:

FDR $=\frac{\text { Pembiayaan }}{\text { Danapihakketiga }} \times 100 \%$

Berdasarkan Surat Edaran BI No9/29/DPbS tahun 2007 tentang Penilaian Tingkat Kesehatan Bank Perkreditan Rakyat Berdasarkan Prinsip Syariah, klasifikasi tingkat FDR secara rinci adalah sebagai berikut :

Tabel 3 Matriks Kriteria Peringkat Komponen FDR

\begin{tabular}{ll}
\hline Rasio(\%) & Peringkat \\
\hline \hline FDR $\leq 75$ & Sangat sehat \\
$75<$ FDR $\leq 85$ & Sehat \\
$85<$ FDR $\leq 100$ & Cukup sehat \\
$100<$ FDR $\leq 120$ & Kurang sehat \\
FDR $>120$ & Tidak sehat \\
\hline \hline
\end{tabular}

Sumber: SE BI No 9/24/DPbS tahun 2007

3. Non Performing Financing (NPF) Non Performing Financing(NPF) atau Non Performing Loan (NPL) adalah kredit bermasalah yang terdiri dari kredit yang berklasifikasi Kurang Lancar, Diragukan dan Macet. Termin NPL diperuntukkan bagi bank umum, sedangkan NPF untuk bank syariah. Rasio ini menunjukan bahwa kemampuan manajemen bank dalam mengelola pembiayaan bermasalah yang diberikan oleh bank (Stiawan 2009).Semakin tinggi rasio ini maka semakin buruk kualitas pembiayaan suatu bank. Hal ini dikarenakan pembiayaan merupakan sektor terbesar dalam menyumbang pendapatan bagi bank.

NPF adalah tingkat pengembalian kredit yang diberikan deposan kepada bank dengan kata lain NPF merupakan tingkat kredit macet pada bank tersebut. NPF diketahui dengan cara menghitung Pembiayaan Non Lancar terhadap Total 
Pembiayaan. Apabila semakin rendah NPF maka bank tersebut akan semakin tinggi keuntungannya, sebaliknya bila tingkat NPF tinggi bank tersebut akan mengalami kerugian yang diakibatkan tingkat pengembalian kredit macet. NPF dapat dirusmuskan sebagai berikut:
$\mathrm{NPF}=\frac{\text { PembiayaanTidakLancar }}{\text { TotalPembiayaan }} \times 100 \%$

Berdasarkan Surat Edaran BI No. 9/29/ DPbs tahun 2007 tentang Penilaian Tingkat Kesehatan Bank Perkreditan Rakyat Berdasarkan Prinsip Syariah, klasifikasi tingkat NPFsecara rinci adalah sebagai berikut :

Tabel 4 Matriks Kriteria Peringkat Komponen NPF

\begin{tabular}{ll}
\hline \hline Rasio $(\%)$ & Peringkat \\
\hline \hline $\mathrm{NPF}<7$ & Sangat sehat \\
$7 \leq \mathrm{NPF}<10$ & Sehat \\
$10 \leq \mathrm{NPF}<13$ & Cukup sehat \\
$13 \leq \mathrm{NPF}<16$ & Kurang sehat \\
$\mathrm{NPF} \geq 16$ & Tidak sehat \\
\hline \hline
\end{tabular}

Sumber: SE BI No9/29/DPbS tahun 2007

4. Biaya Operasional terhadap Pendapatan Operasional (BOPO) BOPOatau sering juga disebut Rasio Efisiensi Operasional adalah perbandingan antara biaya operasional dengan pendapatan operasional. Rasio biaya operasional digunakan untuk mengukur tingkat efisiensi dan kemampuan bank dalam melakukan kegiatan operasi (Dendawijaya, 2005). Semakin rendah nilai BOPO berarti semakin efisien bank tersebut dalam mengendalikan biaya operasionalnya, dengan adanya efisiensi biaya maka keuntungan yang diperoleh bank akan semakin besar.

Nilai BOPO menggambarkan upaya bank untuk meminimalkan reisiko operasional, yang merupakan ketidak pastian mengenai kegiatan usaha bank.Risiko operasional berasal dari kerugian operasional bila terjadi penurunan keuntungan yang dipengaruhi oleh struktur biaya operasional bank dan kemungkinan terjadinya kegagalan atas jasa-jasa dan produk-produk yang ditawarkan. BOPO dapat dirusmuskan sebagai berikut:

BOPO $=\frac{\text { Biaya Openasional }}{\text { Pendapatanopenasional }} \times 100 \%$

Berdasarkan Surat Edaran BI No. 9/29/DPbs tahun 2007 tentang Penilaian Tingkat Kesehatan Bank Perkreditan Rakyat Berdasarkan Prinsip Syariah, klasifikasi BOPO secara rinci adalah sebagai berikut: 
Tabel 5. Matriks Kriteria Peringkat Komponen BOPO

\begin{tabular}{ll}
\hline \hline Rasio $(\%)$ & Peringkat \\
\hline \hline BOPO $\leq 83$ & Sangat sehat \\
$83<\mathrm{BOPO} \leq 85$ & Sehat \\
$85<\mathrm{BOPO} \leq 87$ & Cukup sehat \\
$87<\mathrm{BOPO} \leq 89$ & Kurang sehat \\
$\mathrm{BOPO}>89$ & Tidak sehat \\
\hline \hline
\end{tabular}

Sumber: SE BI No9/29/DPbS tahun 2007

\section{Variabel Makro Ekonomi}

1. Inflasi

Inflasi didefinisikan sebagai suatu kenaikan tingkat harga secara keseluruhan di dalam suatu perekonomian (Mankiw 2006). inflasi adalah peristiwa moneter yang menunjukkan suatu kecenderungan akan naiknya harga barang secara umum, yang berarti terjadinya penurunan nilai uang. Menurut pandangan Keynes, inflasi disebabkan oleh gap antara kemampuan ekonomi masyarakat terhadap keinginankeinginannya terhadap barang. Gap disini adalah permintaan masyarakat terhadap barangbarang lebih besar daripada jumlah yang tersedia sehingga terjadi kenaikan harga. Inflasi dapat diukur dengan indeks harga barang-barang konsumsi dari tahun ke tahun.

Inflasi yang meningkat berdampak pada nilai riil tabungan yang merosot karena masyarakat akan mempergunakan hartanya untuk mencukupi biaya pengeluaran. Dengan kondisi seperti ini, minat masyarakat untuk menabung dan berproduksi menjadi berkurang, serta para investor yang tidak mau berinvestasi di sektor riil.
Harga meningkat dengan cepat, masyarakat akan kewalahan menanggung dan mengimbangi harga kebutuhan sehari-hari yang terus meningkat. Bank akan mengalami kesulitan dalam memperoleh dana pihak ketiga yang merupakan sumber utama modal bank. Bagi bank, inflasi akan menyebabkan naiknya biaya produksi maupun biaya operasional bank. Hal ini menjadikan bank kesulitan menyalurkan dana serta menanggung biaya dari modal yang ada sehingga pada akhirnya merugikan bank itu sendiri yang berimbas pada profitabilitas bank yang bersangkutan.

2. Suku Bunga

Bunga adalah imbal jasa atas pinjaman uang yang merupakan suatu kompensasi kepada pemberi pinjaman atas manfaat kedepan dari uang pinjaman tersebut apabila diinvestasikan (BI 2001). Jumlah pinjaman tersebut disebut pokok utang (principal). Persentase dari pokok utang yang dibayarkan sebagai imbal jasa (bunga) dalam suatu periode tertentu disebut suku bunga.

Secara teoretis terdapat dua jalur utama mekanisme 
transmisi kebijakan moneter, yaitu melalui jalur jumlah uang yang beredar dan jalur harga melalui suku bunga. Jalur suku bunga merupakan channel yang penting untuk perekonomian Indonesia. Pengujian empiris mengungkapkan bahwa pengaruh suku bunga terhadap inflasi mempunyai hubungan yang lebih stabil dibandingkan dengan agregat moneter. Upaya untuk menekan fluktuasi tingkat sukubunga tergantung pada keberhasilan mengendalikan gejolak di pasar uang.

\section{MATERI DAN METODE}

\section{Jenis penelitian}

Penelitian ini bersifat kuantitatif dengan pendekatan yang digunakan adalah pendekatan korelasional. Pendekatan jenis ini bertujuan untuk melihat apakah variabel independen memiliki pengaruh terhadap variabel dependen atau tidak. Berangkat dari suatu teori, gagasan para ahli, ataupun literatur terkait, kemudian dikembangkan menjadi permasalahan-permasalahan yang diajukan untuk memperoleh pembenaran (verifikasi) dalam bentuk dukungan data empiris. Bentuk penelitian kuantitatif penulis gunakan untuk mengetahui bagaimana pengaruh faktor internal dan faktor eksternal terhadap profitabilitas BPRS di Indonesia.

\section{Jenis dan Sumber Data}

Jenis data yang digunakan dalam penelitian ini adalah data sekunder berupa data deret waktu (time series). Data sekunder yang digunakan diambil dari beberapa sumber, yaitu Statistik Perbankan Syariah dari website resmi Otoritas Jasa Keuangan berupa data statistik perkembangan BPRS, website resmi Badan Pusat Statistik dan Bank Indonesia berupa data tingkat inflasi dan suku bunga. Data yang dianalisis adalah data laporan keuangan bulanan BPRS dan data bulanan tingkat inflasi serta suku bunga dari Januari 2013 sampai Desember 2015.

Data sekunder yang digunakan diuraikan dalam Tabel 6 sebagai berikut :

\section{Tabel 6. Variabel-variabel Penelitian}

\begin{tabular}{|c|c|c|}
\hline Variabel & Ketrangan & Sumber \\
\hline ROA & $\begin{array}{l}\text { Persentase laba bersih } \\
\text { sebelum pajak terhadap total } \\
\text { asset. }\end{array}$ & Statistik perbankan syariah OJI \\
\hline CAR & $\begin{array}{l}\text { Persentase modal bank } \\
\text { terhadap aktiva tertimbang } \\
\text { menurut risiko. }\end{array}$ & $\begin{array}{l}\text { Statistik perbankan syariah } \\
\text { OJK }\end{array}$ \\
\hline FDR & $\begin{array}{l}\text { Persentase jumlah } \\
\text { pembiayaan terhadap total } \\
\text { dana pihak ketiga. }\end{array}$ & $\begin{array}{l}\text { Statistik perbankan syariah } \\
\text { OJK }\end{array}$ \\
\hline NPF & $\begin{array}{lrr}\text { Perbandingan } & \text { antara } & \text { kredit } \\
\text { bermasalah } & \text { dengan } & \text { total }\end{array}$ & $\begin{array}{l}\text { Statistik perbankan syariah } \\
\text { OJK }\end{array}$ \\
\hline
\end{tabular}




\begin{tabular}{llll} 
& kredit. & & \\
BOPO & Perbandingan antara total & Statistik perbankan syariah \\
& biaya operasional dengan total & OJK \\
& pendapatan operasional. & \\
Suku & Suku bunga deposito Laporan Kebijakan Moneter \\
Bunga & berjangka tiga bulan yang Bank Indonesia \\
& dipublikasikan oleh Bank & \\
& Indonesia \\
Inflasi & $\begin{array}{l}\text { Persentase kenaikan indeks Badan Pusat Statistik } \\
\text { harga konsumen (IHK). }\end{array}$ \\
\hline \hline
\end{tabular}

Model Penelitian

Metode yang digunakan dalam penelitian adalah Ordinary Least Square (OLS). Regresi linear berganda merupakan regresi dimana variabel terikat yaitu variabel Y dalam hal ini adalah profitabilitas BPRS yang dihubungkan dengan lebih dari satu variabel bebas.Variabel bebas yang digunakan yaituCAR, FPDR, BOPO, NPF, Inflasi dan Suku bunga. Persamaan estimasi menggunakan model OLSdapat dituliskan dalam bentuk sebagai berikut :

$$
\begin{aligned}
& Y=a+b_{1} X_{1}+b_{2} X_{2}+b_{3} X_{3}+b_{4} X_{4}+b_{5} X_{5}+b_{6} X_{6}+e \\
& \text { Keterangan: } \\
& Y \quad=\text { ROA (persen) } \\
& \text { a } \quad \text { Konstanta } \\
& b_{1}-b_{6} \quad=\text { Koefisien regresi variabel independen } \\
& x_{1} \quad=\text { CAR (persen) } \\
& x_{2}=\text { BOPO (persen) } \\
& x_{3} \quad=\text { NPF (persen) } \\
& x_{4} \quad=\text { FDR (persen) } \\
& x_{5} \quad=\text { Inflasi (persen) } \\
& x_{6} \quad=\text { Suku Bunga (persen) } \\
& e \quad=\text { eror }
\end{aligned}
$$

\section{Batasan dan Definisi \\ Operasional}

Variabel-variabel yang digunakan dalam penelitian ini adalah sebagai berikut :

1. ROA adalah perbandingan antara laba sebelum pajak terhadap total aktiva BPRS. Rasio ini digunakan untuk mengukur kemampuan manajemen bank dalam memperoleh keuntungan (laba) secara keseluruhan dari pengelolaan aset yang dimiliki.
2. CAR adalah perbandingan antara modal bank terhadap aktiva tertimbang menurut risiko (ATMR). Rasio ini digunakan untuk mengukur kecukupan modal yang dimiliki bank untuk menunjang aktiva yang mengandung atau menghasilkan risiko.

3. FDR adalah perbandingan antara seluruh pembiayaan yang disalurkan BPRS trhadap dana pihak ketiga. Rasio ini digunakan untuk tingkat likuiditas bank atau 
kemampuan bank dalam membayar kembali penarikan dana yang dilakukan deposan dengan mengandalkan pembiayaan yang diberikan sebagai sumber likuiditasnya.

4. NPF adalah perbandingan antara pembiayaan tidak lancar terhadap total pembiayaan. Rasio ini digunakan untuk mengukur kemampuan manajemen bank dalam mengelola pembiayaan bermasalah yang diberikan.

5. BOPO adalah perbandingan antara biaya operasional terhadap pendapatan operasional. Rasio ini digunakan untuk mengukur tingkat efisiensi dan kemampuan bank dalam melakukan kegiatan operasi.

6. Inflasi adalah peristiwa moneter yang menunjukkan suatu kecenderungan akan naiknya harga barang secara umum atau menurunya nilai uang.

7. Suku bunga adalah imbal jasa atas pinjaman uang yang merupakan suatu kompensasi kepada pemberi pinjaman atas manfaat kedepan dari uang pinjaman tersebut apabila diinvestasikan.

\section{Metode Pengolahan dan Analisis Data}

Proses pengolahan data pada penelitian dilakukan dengan menggunakan bantuan software Microsoft Excel 2007 dan Eviews 6.Metode analisis data yang digunakan adalah analisis deskriptif dan kuantitatif. Analisis deskriptif digunakan untuk memberikan suatu gambaran secara umum mengenai kondisi makro dan kinerja BPRS di Indonesia. Metode kuantitatif yang digunakan dalam penelitian ini adalah Ordinary Least Square (OLS). Metode OLS digunakan untuk mengetahui faktor-faktor apa saja yang memiliki pengaruh terhadap profitabilitas BPRS. Analisis variabel yang paling berpengaruh dalam penelitian ini didasarkan pada nilai koefisien yang paling besar dari hasil estimasi model yang diperoleh.

\section{Evaluasi Model}

Setelah selesai melakukan pengolahan data, harus dilakukan evaluasi terhadap model estimasi yang dihasilkan. Metode estimasi yang dihasilkan melalui metode analisis Ordinary Least Square (OLS) harus dievaluasi berdasarkan kriteria ekonometrika, kriteria statistik, kriteria ekonomi.

\section{Uji kriteria Ekonometrika}

1. Uji Normalitas

Ujinormalitas bertujuan untuk mengetahui distribusi data dalam variabel yang akan digunakandalam penelitian. Data yang baik dan layak digunakan dalam penelitian adalah data yangmemiliki distribusi normal.Uji yang digunakan untuk melihat kenormalan data yaitu dengan Jarque Bera Test atau dengan melihat plot dari sisaan.

2. Uji Autokorelasi

Menurut Firdaus (2011), autokorelasi merupakan gangguan pada fungsi regresi yang berupa korelasi di antara faktor gangguan. Autokorelasi ini akanmenyebabkan model 
menjadi tidak efisienmeskipun tidak bias dan konsisten. Pengujian untuk mendeteksi gejala autokorelasi dapat dilakukan dengan menggunakan uji Breush and Godfrey Serial Correlation lagrange Multiplier Test.

3. Uji Heteroskedastisitas

Suatu model regresi linear harus memiliki varians yang sama (Gujarati 2006). Uji heteroskedastisitas bertujuan untuk menguji apakah dalam sebuah model regresi terjadi ketidaksamaan varian dari residual untuk peubah bebas yang diketahui.Pengujian yang dapat dilakukan untuk melihat gejala ini adalah dengan menggunakanuji Heteroskedasticity.

4. Uji Multikolinieritas

Multikolinearitas adalah kondisi dimana peubah-peubah bebas memiliki korelasi diantara satu dengan yang lainnya.m Untuk mengetahui ada tidaknya multikolinearitas dapat dilihat melalui correlation matrix, dimana batas terjadinya korelasi antar sesama variabel bebas adalah tidak lebih dari $|0.80|$. Selain correlation matric, apabila terdapat nilai korelasi yang lebih tinggi dari $|0.80|$, maka multikoliniearitas dapat diabaikan selama nilai korelasi tersebut tidak melebihi nilai Adjusted R-squared.

\section{Uji Kriteria Statistika}

1. Uji Koefisien Determinasi $\left(\mathrm{R}^{2}\right)$ Analisis determinasi dalam regresi linear berganda digunakan untuk menunjukkan seberapa besar prosentase variasi variabel independen yang digunakan dalam model mampu menjelaskan variasi variabel dependen.

\section{Uji Statistik F ( Uji Simultan)}

Uji $F$ dilakukan untuk melihat pengaruh variabel-variabel independen secara bersamasama terhadap variabel dependen. Selain itu dengan uji $F$ ini dapat diketahui pula apakah model regresi linier yang digunakan sudah tepat atau belum. Pengujian ini melihat hasil uji signifikansi yang berada di bawah 5 persen (0.05). Jika nilai sig < 0.05 maka Ho diterima, namun jika nilai sig $>0.05$ maka $\mathrm{H}_{0}$ ditolak.

3. Uji Statistik t (Uji Parsial)

Uji $t$ digunakan untuk mengetahui pengaruh variabel independen (X1, X2,.....Xn) secara sendiri atau masingmasing terhadap variabel dependen (Y). Jika nilai signifikan diatas $\alpha=5$ persen berarti masing-masing variabel independen tidak mempunyai pengaruh terhadap variabel dependen. Demikian juga sebaliknya, jika nilai signifikansi berada di bawah nilai $\alpha=$ 5persen berarti masing-masing variabel independen mempunyai pengaruh terhadap variabel dependen.

\section{Uji Kriteria Ekonomi}

Evaluasi model estimasi berdasarkan kriteria ekonomi dilakukan untuk membandingkan kesesuaian tanda dan nilai estimator dengan teori ekonomi dan kesesuaian dengan logika. Pengaruhnya variabel independen 
terhadap variabel dependen harus dijelaskan dengan penjelasan ekonomi.

\section{HASIL DAN PEMBAHASAN}

\section{Gambaran Umum Kinerja Bank Pembiayaan Rakyat Syariah dan Kondisi Makro di Indonesia}

Bank Pembiayaan Rakyat Syariah (BPRS) sebagai bagian dari perbankan syariah harus mampu memberikan risiko yang lebih kecil daripada risiko yang diberikan bank konvensional. Untuk meminimalkan risiko maka harus dilakukan manajemen dana dengan baik, diantaranya dengan memperhatikan kecukupan modal yang ditunjukkan dengan CAR.

Nilai CAR BPRS berada di atas 8 persen, sesuai dengan batas minimal yang ditentukan oleh BI. Namun CAR BPRS mengalami penurunan yang cukup signifikan pada bulan Februari 2013 sampai Desember 2014 dan mulai mengalami peningkatan kembali ketika memasuki bulan Januari 2015. Kondisi permodalanyang mengalami penurunan mengakibatkanBPRS tidak dapat leluasa melakukan pengembangan bisnis dan akanmemberikan kontribusi yang kurang baik bagi profitabilitas.

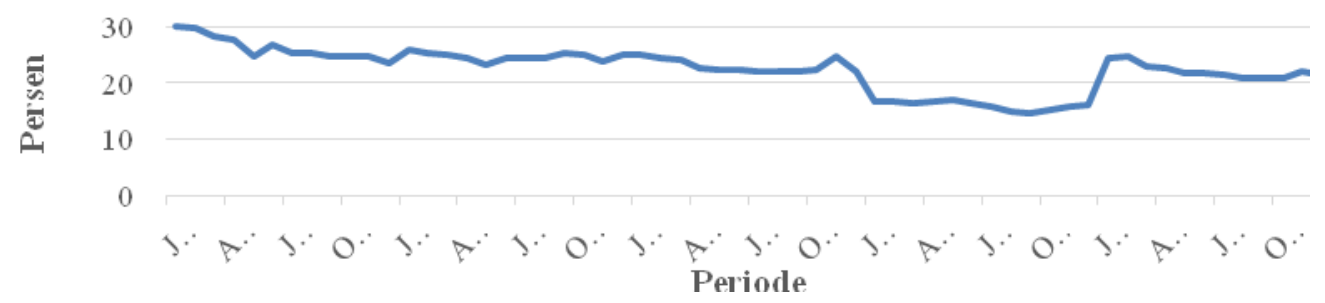

Sumber: Statistik Perbankan Syariah, OJK 2015

Gambar 3 Perkembangan CAR BPRS di Indonesia tahun 2011-2015.

Sumber dana pembiayaan BPRS selain dari modal sendiri, juga berasal dari dana pihak ketiga. Pemberian pembiayaan kepada masyarakat dapat diketahui dengan melihat nilai FDR. Nilai FDR BPRS setiap tahunya memiliki proporsi yang cukup tinggi. nilai tersebut diatas ketentuan minimum yang sudah ditetapkan oleh BI yaitu di kisaran 85 - 100 persen, walaupun secara pertumbuhannya setiap tahun mengalami fluktuasi. Hal ini dapat disebabkan oleh manajemen BPRS yang belum efektif dalam hal pengelolaan dana.

FDR menggambarkan kondisi likuiditas BPRS. Nilai FDR yang tinggi menandakan jumlah dana yang disalurkan lebih besar dari dana yang behasil dihimpun. Rasio likuiditas yang tinggi apabila tidak dikelola dengan baik maka akan membahayakan bagi BPRS tersebut.

Penyaluran pembiayaan harus selalu diawasi dengan pengelolaan manajemen risiko yang ketat. Hal tersebut untuk meminimalisir terjadinya pembiayaan bermasalah. Pembiayaan yang dilakukan secara efektif akan menstabilkan nilai FDR. Jika nilai FDR menurun dapat berakibat pada penurunan jumlah bagi hasil yang diterima oleh deposan maupun oleh BPRS itu sendiri. 
Penurunan jumlah bagi hasil yang penurunan pada tingkat laba BPRS. diterima BPRS akan menyebabkan

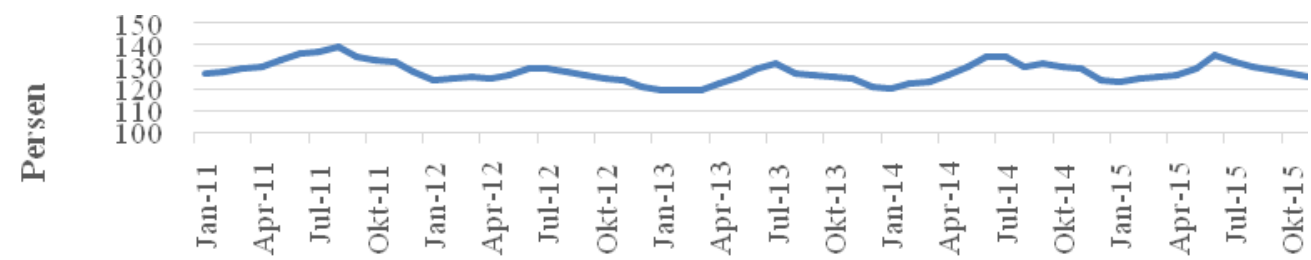

Periode

Sumber: Statistik Perbankan Syariah, OJK 2015

Gambar 4 Perkembangan FDR BPRS di Indonesia tahun 2011-2015

Hal penting yangperlu juga diperhatikan oleh pengelola bank termasuk di dalamnya Bank Pembiayaan rakyat Syariah (BPRS) adalah kualitas pembiayaan yang disalurkan. Kualitas penyaluran pembiayaan berdasarkan kolektibilitasnya terdiri atas: 1) Pembiayaan Lancar, 2) Dalam Perhatian Khusus, 3) Kurang Lancar, 4) Diragukan, dan 5) Macet. Yang dimaksud dengan Non Performing Financing (NPF)adalah pembiayaan dengan kolektibilitas kurang lancar, diragukan dan macet.
Rasio NPF diperoleh dari pembagian antara jumlah ketiga kolektibilitas tersebut dengan jumlah pembiayaan yang disalurkan. Dapat dilihat pada Gambar 6 bahwa rasio NPF BPRS Indonesia periode 2011 hingga 2015mengalami peningkatan. Nilai NPF BPRS pada tahun 2015 mencapai nilai tertinggi yaitu 10.3 persen.Data tersebut menggambarkan kemampuan manajemen BPRS dalam mengelola pembiayaan bermasalah yang diberikan oleh bank masih belum optimal.

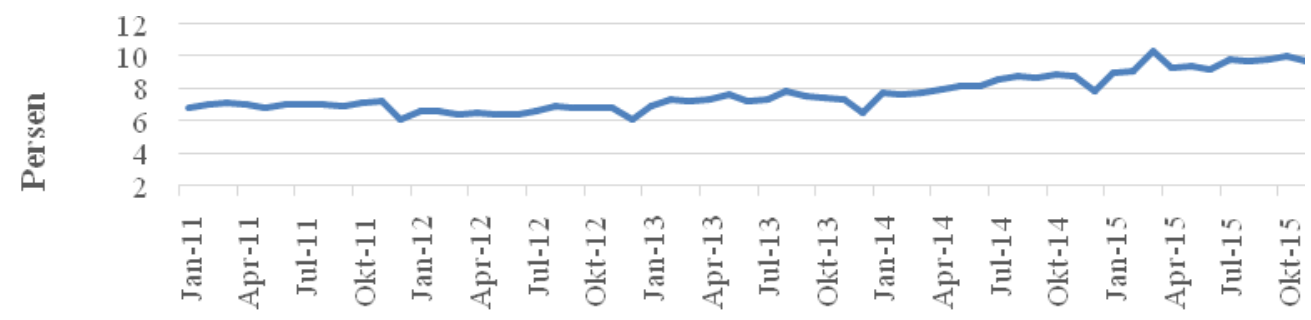

Periode

Sumber : Statistik Perbankan Syariah, OJK 2015

Gambar 5 Perkembangan NPF BPRS di Indonesia tahun 2011-2015

Bank Pembiayaan Rakyat Syariah (BPRS) sebagai financialintermediary harus mampu efisien dalam menjalankan operasional-nya.

Gambaran mengenai efisiensi BPRS dicerminkan oleh nilai BOPO. Pada Gambar 6 dapat diketahui bahwa perkembangan efisiensi BPRS yang diproksikan oleh nilai BOPO.Pada tahun 2011 `nilai BOPO BPRS mencapai nilai terendah yaitu 
sebesar 76.29 persen. Namun, pada tahun 2015 presentase BOPO BPRS mengalami peningkatan yang cukup signifikan jika dibandingkan dengan tahun sebelumnya (Gambar 6). Nilai BOPO pada tahun 2014 mencapai nilai tertinggi yaitu 89.77 persen.

Tingginya nilai BOPO BPRS menunjukkan bahwa efisiensi BPRS menurun dari tahun ke tahun. Hal ini dapat disebabkan oleh BPRS yang masih dalam tahap ekspansi, sehingga membutuhkan upaya besar dalam pembangunan infrastruktur baru. Rasio BOPO pada BPRS menggambarkan efisiensi peran BPRS dalammemajukan perekonomian rakyat melalui sektor unit usaha mikro kecil dan menegah (UMKM). UMKM merupakan objek utama pembiayaan BPRS dan juga memiliki peranan dalam menggerakkan sektor riil sehingga perkembangnnya patut untuk diperhatikan(Fauzi 2014).

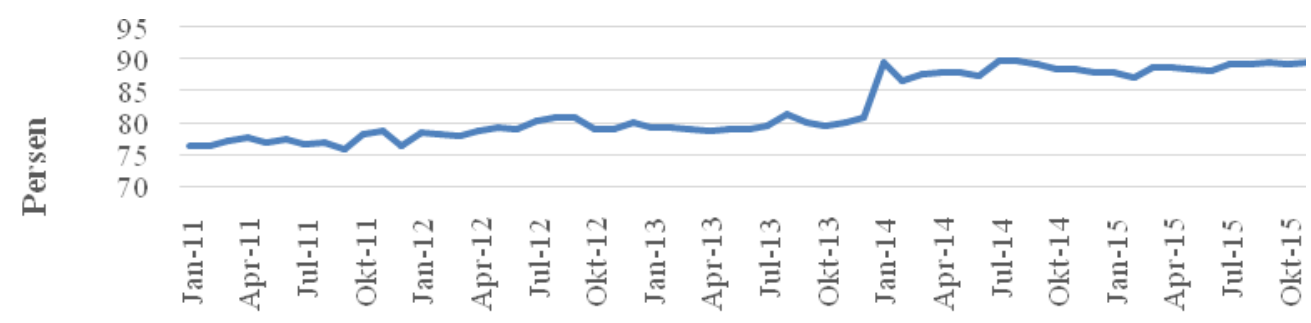

Periode

Sumber : Statistik Perbankan Syariah, OJK 2015

Gambar 6 Perkembangan BOPOBPRS di Indonesia Periode 2011-2015

Inflasi dapat berpengaruh buruk bagi perekonomian. Peningkatan inflasi akan mengakibatkan minat masyarakat untuk menabung, berinvestasi danberproduksi menjadi berkurang.

Inflasi akan mendorong keinginan masyarakat untuk memegang uang, hal ini akan mengurangi jumlah dana yang tersedia di bank akibat menurunnya tingkat tabungan pada sektor perbankan. Penurunan pada DPK ini akan menyebabkan aset riil dari sektor perbankan termasuk BPRS ikut menurun dan berpengaruh pada kegiatan penyaluran pembiayaan yang menurun. Selama periode 2011 hingga 2015, Inflasi di Indonesia mengalami fluktuasi seperti yang ditunjukan oleh Gambar 7. Kondisi tersebut memberikan dampak negatif terhadap kinerja BPRS. Hal ini dikarenakan pendapatan utama BPRS terfokus pada keuntungan dari pembiayaan yang bergerak pada sektor riil. Naiknya biaya produksi dan biaya operasional yang disebabkan oleh inflasi membuat risiko yang dihadapi BPRS menjadi tinggi. 


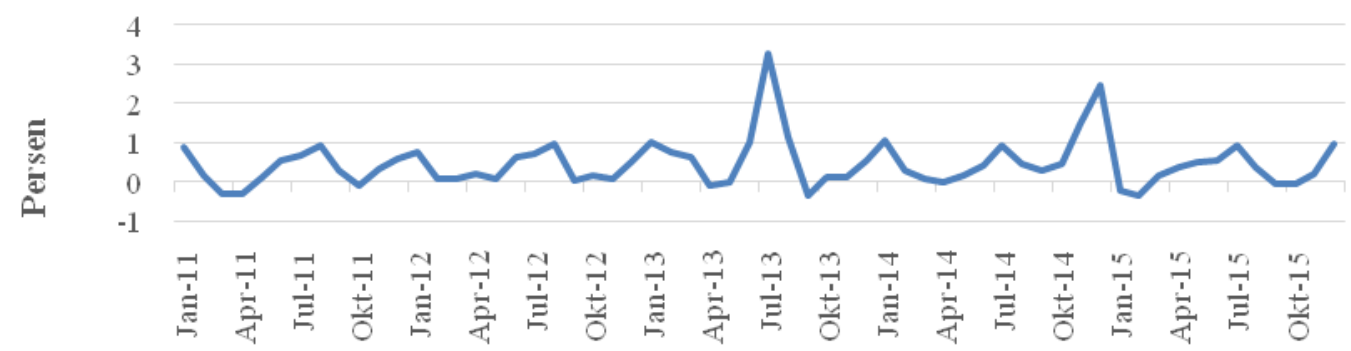

Periode

Sumber :Badan Pusat Statistik 2015

Gambar 7 Inflasi di Indonesia tahun 2011-2015

Bank Indonesia memiliki tugas untuk menjaga stabilitas moneter antara lain melalui instrumen suku bunga dalam operasi pasar terbuka. Kebijakan moneter melalui penerapan suku bunga yang terlalu ketat, akan cenderung bersifat mematikan kegiatan ekonomi. Begitu pula sebaliknya. Kenaikan suku bunga mengakibatkan ketatnya likuditas perbankan, sehingga pihak bank kesulitan mendapatkan dana murah dari pihak ketiga (giro, tabungan, deposito). Pada Gambar 8 dapat dilihat bahwa tingkat suku bunga mengalami peningkatan yang cukup signifikan pada tahun 2013 dan cenderung stabil sampai tahun 2015.

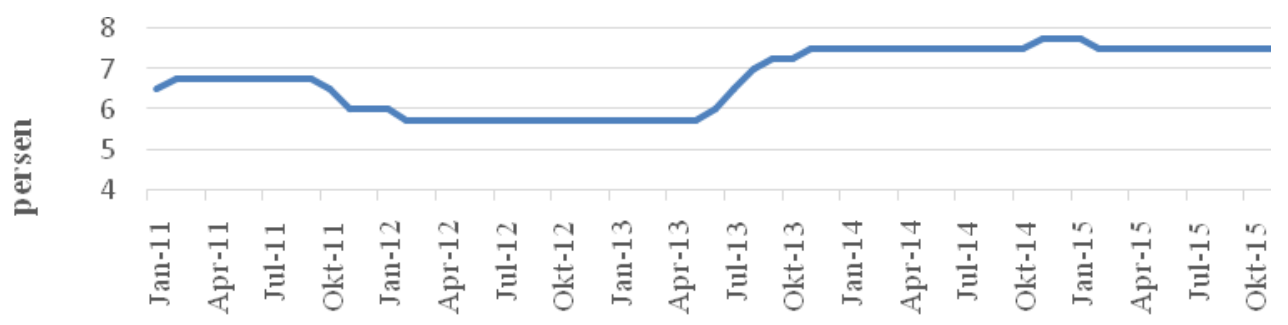

Sumber : Bank Indonesia 2015 (diolah)

Periode

Gambar 8 Suku Bunga di Indonesia tahun 2011-2015

Faktor-faktor yang

Memengaruhi Profitabilitas

Bank Pembiayaan Rakyat

Syariah (BPRS) di Indonesia

Untuk mengetahui faktor-

faktor yang memengaruhi profitabilitas BPRS di Indonesia dilakukan melalui analisis regresi linier berganda. Dalam hal ini akan dikaji bagaimana variabel independen yang ada dapat mempengaruhi variabel dependen.
Model etimasi yang dihasilkan harus dievaluasi berdasarkan kriteria ekonometrika, kriteria statistik, kriteria ekonomi.

\section{Tahapan Evaluasi Model}

Berdasarkan Kriteria

Ekonometrika

1. Uji Normalitas.

Pengujian normalitas dilakukan dengan Jarque-Bera Test yang terdapat dalam software Eviews 
6. Hasil perhitungan dengan menggunakan software Eviews 6 menghasilkan output pada Lampiran 2. Dari hasil tersebut diperoleh nilai $p$-value sebesar 0.873464 yanglebih besar dari taraf nyata 5 persen menandakan tidak cukup bukti untuk melakukan penolakan terhadap $\mathrm{H}_{0}$, dan mengindikasikan residual berdistribusi normal.

2. Uji Autokorelasi

Pengujian autokorelasi pada perangkat Eviews 6 dapat diketahui melaui Serial Corelation LM test. Nilai probability obs*R-squared pada model persamaan adalah 0.38 yang artinya bernilai lebih besar dari $\alpha=5$ persen. Hal ini menunjukkan bahwa model persamaan yang digunakan dalam penelitian ini tidak memiliki masalah autokorelasi.Hasil uji tersebut dapat dilihat pada Tabel 7 berikut.

\section{Tabel 7 Hasil Uji Autokorelasi}

Breusch-Godfrey Serial Correlation LM Test:

\begin{tabular}{llll}
\hline \hline F-statistic & 0.714530 & Prob. F(2,25) & 0.4991 \\
Obs*R-squared 1.892503 & Prob. Chi-Square(2) & 0.3882 \\
\hline
\end{tabular}

3. HasilUji Heteroskedastisitas

Pengujian autokorelasi pada perangkat Eviews 6 dapat diketahui melaui uji BreuschPagan-Godfrey. Hasil pengujian menunjukkan bahwa nilai probability obs*R-squared pada model persamaan adalah 0.0902 yang artinya bernilai lebih besar dari $\alpha=5$ persen. Oleh karena itu, model persamaan yang digunakan dalam penelitian ini tidak memiliki masalah heteroskedastisitas.Hasil uji tersebut dapat dilihat pada Tabel 8 berikut.

\section{Tabel 8 Hasil uji heteroskedaastisitas}

\begin{tabular}{llll}
\hline \multicolumn{4}{l}{ Breusch-Godfrey Serial Correlation LM Test: } \\
\hline \hline F-statistic & 2.097951 & Prob. F(7,27) & 0.0786 \\
Obs*R-squared & 12.33033 & Prob. Chi-Square(7) & 0.0902 \\
\hline \hline
\end{tabular}

4. Hasil Uji Multikolinearitas. Persyaratan kecukupan (sufficient condition) untuk terbebas dari pelanggaran asumsi multikolinearitas ini adalah nilai koefisien antara variabel independen pada model tidak melebihi nilai $\mathrm{R}^{2}$. Hasil perhitungan nilai koefisien korelasi dengan menggunakan software Eviews 6 menghasilkan output pada Lampiran 5 . Dengan melihat hasil output tersebut, tidak terdapat nilai koefisien korelasi yang melebihi nilai $\mathrm{R}^{2}$ sebesar 0.92 pada variabel independen dalam model, dengan demikian persyaratan kecukupan telah terpenuhi sehingga dapat disimpulkan bahwa tidak terjadi pelanggaran asumsi multiko- 
linearitas dalam estimasi model penelitian.

\section{Tahapan Evaluasi Model Berdasarkan Kriteria Statistika}

Berdasarkan hasil analisis data diperoleh nilai koefisien determinasi $\left(\mathrm{R}^{2}\right)$ pada model yaitu 0.9217. Nilai tersebut menandakan bahwa 92.17persenkeragaman dari variabel dependen dapat dijelaskan oleh variabel-variabel independennya, sedangkan sisanya sebesar 7.83 persen dijelaskan oleh variabel lain di luar model.

Dari hasil estimasi diketahui nilai Prob (F-Statistic) pada model memiliki nilai 0.000000 yang lebih kecil dibandingkan taraf nyata $\alpha$ sebesar 5 persen sehingga dapat disimpulkan bahwa setidaknya ada satu variabel independen yang berpengaruh signifikan terhadap profitabilitas BPRS di Indonesia dengan tingkat kepercayaan 95 persen.Uji-t dilakukan untuk melihat masing-masing variabel bebas secara statistik berpengaruh nyata terhadap profitabilitas BPRS di Indonesia. Uji tersebut dapat dilakukan dengan melihat nilai $t$ statistic dari masing-masing variabel yang lebih kecil dari taraf nyata $\alpha=5$ persen. Variabel independen CAR, FDR, NPF, BOPO dan inflasi memiliki nilai probabilitas lebih kecil daripada taraf nyata $\alpha=5$ persen. Hal ini berarti variabel-variabel independen tersebut secara parsial berpengaruh signifikan terhadap profitabilitas BPRS di Indonesia. Variabel suku bunga memiliki nilai probabilitas lebih besar dari $\alpha=5$ persen. Hasil ini berarti variabel suku bunga secara parsial tidak memengaruhi profitabilitas BPRS di Indonesia.

\section{Tahapan Evaluasi Model} Berdasarkan Kriteria Ekonomi

Estimasi model yang diperoleh dari hasil pengolahan data menunjukkan hasil cukup baik karena telah memenuhi syarat-syarat pengujian model. Selanjutnya, evaluasi dengan kriteria ekonomi perlu dilakukan dengan melihat tanda dan besaran masing-masing variabel bebas. Tabel 9 menyajikan hasil estimasi untuk masing-masing variabel dalam model.

\section{Tabel 9 Hasil Estimasi Model Faktor-faktor yang Memengaruhi} Profitabilitas BPRS di Indonesia.

\begin{tabular}{lllll}
\hline \hline Variabel & Koefisien & Std.error & t-statistik & $\begin{array}{l}\text { Prob.(t- } \\
\text { tatistik) }\end{array}$ \\
\hline \hline CAR & 0.001120 & 0.012067 & 0.101832 & $\mathbf{0 . 0 0 9 6}^{*}$ \\
FDR & 0.004857 & 0.008047 & 0.837520 & $\mathbf{0 . 0 0 9 7}^{*}$ \\
NPF & -0.131269 & 0.017778 & -2.298939 & $\mathbf{0 . 0 2 9 5}^{*}$ \\
BOPO & -0.005342 & 0.038114 & -0.347890 & $\mathbf{0 . 0 3 0 6}^{*}$ \\
INF & -0.054840 & 0.004141 & -1.983581 & $\mathbf{0 . 0 1 7 6 *}$ \\
BIrate & -0.090711 & 0.036226 & -1.595500 & 0.1222 \\
C & 0.029727 & 0.013345 & 1.815717 & 0.0805 \\
\hline \hline
\end{tabular}

Keterangan: * signifikan pada taraf nyata $5 \%$ 
Variabel CAR berpengaruh positif dan signifikan pada taraf nyata $(\alpha=0.05)$ terhadap ROA dan memiliki koefisien 0.001120.Artinya, peningkatan CAR sebesar 1 persen akan meningkatkan ROA sebesar 0.001120 persen saat variabel lain dianggap konstan. Nilai CAR yang positif dapat dijelaskan bahwa ketika CAR meningkat, maka BPRSmemiliki peluang yang cukup besar untuk melakukan ekspansi pembiayaan atau BPRSmampu untuk menanggung risiko dari setiap aktiva produktif sehingga mampu membiayai operasi bank. Hasil penelitian ini sesuai dengan hipotesis penelitian dan dengan penelitian sebelumnya yang dilakukan oleh dan Stiawan (2009) dan Afifah (2014).

Variabel FDR berpengaruh positif dan signifikan pada taraf nyata $(\alpha=0.05)$ terhadap ROA dan memiliki koefisien 0.004857 . Artinya, peningkatan FDR sebesar 1 persen akan meningkan ROA sebesar 0.004857 persen saat variabel lain dianggap konstan. Nilai FDR yang positif dapat dijelaskan bahwa ketika FDR meningkat maka akan semakin banyak dana pihak ketiga yang dapat dihimpun dari masyarakat sehingga akan memberikan peluang bagi BPRS untuk meningkatkian penyaluran dana. Tingginya penyaluran dana yang diberikan pihak BPRS, akan meningkatkan peluang untuk mendapatkan return dari penggunaan dana tersebut dengan asumsi BPRS tersebut mampu menyalurkan pembiayaan dengan efektif. Hasil penelitian ini sesuai dengan hipotesis penelitian dan dengan penelitian sebelumnya yang dilakukan oleh Afifah (2014) dan Nurhayati (2014).

Variabel NPF berpengaruh negatif dan signifikan pada taraf nyata $(\alpha=0.05)$ terhadap ROA dan memiliki koefisien 0.131269 . Artinya, peningkatan NPF sebesar 1 persen akan menurunkan ROA sebesar 0.131269 persensaat variabel lain dianggap konstan. Nilai NPF yang negatif dapat dijelaskan bahwa ketika terjadi peningkatan NPF maka akan menurunkan perolehan laba. Hal ini dikarenakan peningkatan NPF akan mengakibatkan likuiditas yang dimiliki BPRS menjadi tersendat. BPRS akan kesulitan untuk menyalurkan kembali dana yang dimilikinya karena dana yang dimilikinya tersebut macet. Hasil penelitian ini sesuai dengan hipotesis penelitian dan dengan penelitian sebelumnya yang dilakukan Stiawan (2009) dan Purwanto (2011).

Variabel BOPO berpengaruh negatif dan signifikan pada taraf nyata $(\alpha=0.05)$ terhadap ROA dan memiliki koefisien 0.005342. Artinya, peningkatan BOPO sebesar 1 persen akan menurunkan ROA sebesar 0.005342saat variabel lain dianggap konstan.Nilai BOPO yang negatif dapat dijelaskan bahwa ketika terjadi peningkatan BOPO maka pihak BPRS masih belum efisien dalam menjalankan operasionalnya. Nilai BOPO yang meningkat menunjukan bahwa biaya opersional yang dikeluarkan oleh BPRS meningkat atau pendapatan operasional BPRS menurun.Hasil penelitian ini sesuai dengan hipotesis penelitian 
dan dengan penelitian sebelumnya yang dilakukan Nurhayati (2014) dan Khatimah (2010).

Variabel Inflasi berpengaruh negatif dan signifikan pada taraf nyata $(\alpha=0.05)$ terhadap ROA dan memiliki koefisien 0.054840 . Artinya, peningkatan inflasi sebesar 1 persen akan menurunkan rasio ROA sebesar 0.054840saat variabel lain dianggap konstan. Nilai inflasi yang negatif dapat dijelaskan bahwa ketika inflasi meningkat akan mengakibatkan minat masyarakat untuk menabung dan berinvestasi menjadi berkurang. Hal tersebut mengakibatkan BPRS mengalami kesulitan dalam menghimpun dana sehingga akan berdampak pada penurunan proporsi pembiayaan yang pada akhirnya akan berdampak pada penurunan laba yang diperoleh oleh BPRS.Hasil penelitian ini sesuai dengan hipotesis penelitian dan dengan penelitian sebelumnya yang dilakukan Anggraini (2013) dan Afifah (2014).

Variabel suku bunga berpengaruh negatif namun tidak signifikan pada taraf nyata $(\alpha=0.05)$ terhadap ROAtidak berpengaruh signifikan terhadap profitabilitas (ROA). Praktik operasional Bank Pembiayaan Rakyat Syariah (BPRS) baik penghimpunan maupun penyaluran pembiayaannya menggunakan system bagi hasil dan tidak menerapkan sitem bunga. Bagi hasil atau profit sharing dibuat pada waktu akad dengan pedoman kemungkinan untung dan rugi. Besarnya nisbah bagi hasil berasarkan pada jumlah keuntungan yang diperoleh, dan berdasarkan kesepakatan antara kedua belah pihak yaitu antara pihak BPRS dan nasabah.Hasil penelitian ini sesuai dengan penelitian yang dilakukan Wibowo dan Syaichu (2013).

\section{Faktor yang Paling Berpengaruh terhadap Profitabilitas BPRS di Indonesia} Berdasarkandatahasil

estimasi, Variabel NPF yang merupakan proksi dari kualitas pembiayaan yang disalurkan memiliki nilai koefisien penduga sebesar 0.131269. Nilai tersebut merupakan nilai yang paling besar. Hal ini menunjukkan bahwa NPF merupakan variabel yang paling berpengaruh terhadap profitabilitas BPRS yang diproksiakan oleh ROA. Nilai NPF yang negatif dapat dijelaskan bahwa ketika terjadi peningkatan NPF akan mengakibatkan likuiditas yang dimiliki BPRS menjadi tersendat. BPRS akan kesulitan untuk menyalurkan kembali dana yang dimilikinya karena dana tersebut macet.

Pengelolaan pembiayaan sangat diperlukan oleh BPRS, mengingat fungsi pembiayaan sebagai penyumbang pendapatan terbesar bagi BPRS. Bertambahnya NPF akan mengakibatkan hilangnya kesempatan untuk memperoleh pendapatan dari pembiayaan yang disalurkan. Oleh sebab itu, BPRS membutuhkan sumberdaya manusia yang berkompeten baik dari segi keilmuan ataupunkeahlian. SDM BPRS harus memahami prinsipprinsip syariah yang diterapkan dalam setiap aspek operasional 
BPRS termasuk dalam mendisain produk-produk perbankan dan struktur keuangan syariah (shariah complaint financial products), perjanjian (akad) keuangan dan pelaksanaannya, manajemen likuiditas dan neraca, manajemen risiko, dan sebagainya. Hal tersebut sesuai dengan firman Allah SWT dalam Q.S. Yusuf ayat 55 berikut:

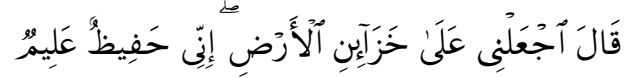

Artinya :"Jadikanlah aku bendaharawan negara (Mesir); sesungguhnya aku adalah orang yang pandai menjaga, lagi berpengetahuan"(Q.S. Yusuf : 55).

Setiap sumberdaya manusia yang ada di dalam suatu lembaga keuangan termasuk BPRSharus senantiasa bekerja efektif, efisien kualitas maupun kuantitas pekerjaannya sehingga daya saing BPRS semakin baik.

\section{KESIMPULAN DAN IMPLIKASI}

1. Kinerja BPRS dan kondisi makro selama periode 2011 hingga 2015 cenderung mengalami fluktuasi, CAR dan FDR cenderung mengalami penurunan sedangkan NPF dan BOPO cenderung mengalami peningkatan, Inflasi cenderung berfluktuasi dan Suku Bunga cenderung stabil memasuki tahun 2015.

2. Faktor-faktor yang berpengaruh signifikan terhadap profitabiltas BPRS di Indonesia adalah CAR, FDR, NPF, BOPO dan inflasi. CAR dan FDR memiliki pengaruh positif terhadap profitabilitas BPRS di Indonesia sedangkan
NPF, BOPO dan Inflasi memiliki pengaruh negatif terhadap profitabilitas BPRS di Indonesia.

3. Variabel yang paling berpengaruh terhadap profitabilitas BPRS di Indonesia adalah NPF. Koefisien NPF yang negatif dapat dijelaskan bahwa ketika terjadi peningkatan NPF akan mengakibatkan likuiditas yang dimiliki BPRS menjadi tersendat. BPRS akankesulitan untuk menyalurkan kembali dana yang dimilikinya karena dana tersebut macet.

\section{Saran}

Manajemen BPRS lebih mitigasi risiko terhadap kinerja BPRS agar senantiasa berada dalam koridor batas yang sudah ditetapkan oleh Bank Indonesia sehingga bisa meminimaliasir risiko yang muncul di masa mendatang dan munculkan kepercayaan nasabah untuk menggunakan produk dan jasa BPRS.

1. Manajemen BPRS lebih mitigasi risikoterhadap kualitas kinerja dan kondisi makro agar BPRS senatiasa memiliki performa dan dayasaing yang baik di lingkup industri perbankan nasional.

2. Manajemen BPRS lebih mitigasi risikoterhadap nilai NPF. Pengelolaan pembiayaan sangat diperlukan oleh BPRS, mengingat fungsi pembiayaan sebagai penyumbang pendapatan terbesar bagi BPRS.

3. Penelitian selanjutnya diharapkan dapat lebih berfokus kepada Bank Pembiayaan Rakyat Syariah (BPRS) tertentu sehingga bisa menggambarkan 
kondisi yang dialami oleh BPRS tersebut.

\section{DAFTAR PUSTAKA}

Nurhayati. 2014. Analisis Faktorfaktor yang Memengaruhi Profitabilitas Bank Umum Syariah di Indonesia Tahun 2008-2012. [Skripsi]. Bengkulu (ID): Universitas Bengkulu.

Fauzi A. 2014. Efisiensi Bank Pembiayaan Rakyat Syariah (BPRS) di Indonesia Periode Tahun 2011-2013. [Skripsi]. Bogor (ID): Institut Pertanian Bogor.

Adawiyah SR. 2016. Pengaruh Pembiayaan Sektor Ekonomi Terhadap Non Performing Financing Bank Pembiayaan Rakyat Syariah. [Skripsi]. Bogor (ID): Institut Pertanian Bogor.

Afifah GZ. 2014. Analisis Faktorfaktor yang Memengaruhi Profitabilitas Bank Umum Syariah (BUS) di Indonesia. [Skripsi]. Bogor (ID): Institut Pertanian Bogor

Anggraini YA. 2013. Analisis Faktor-faktor Yang Memengaruhi Perbedaan Profitabilitas Bank Asing dan Bank Domestik di Indonesia [Skripsi]. Bogor (ID): Institut Pertanian Bogor.

Firdaus M. 2011. Ekonometrika Suatu Pendekata Aplikatif. Jakarta (ID): PT.Bumi Aksara.

Haron S. 2004. Determinants Of Islamic Bank Profitability. Global Journal of Finance and Economics. USA. 1(1):1-22.

Stiawan A. 2009. Analisis Pengaruh Faktor Makroekonomi, Pangsa Pasar dan
Karakteristik Bank Terhadap Profitabilitas Bank Syariah (Studi Kasus Bank Syariah Periode 2005-2008 [Tesis]. Semarang (ID): Universitas Dipenogoro.

Khatimah I. 2010. Pengaruh Kecukupan Modal dan Efisiensi Operasional terhadap Profitabilitas pada PT. BPRS Amanah Ummah Leuwiliang Bogor [Skripsi]. Jakarta (ID): Universitas Islam Negeri Syarif Hidayatullah.

Soemitra A. 2009. Bank dan Lembaga Keuangan Syariah. Jakarta (ID): Kencana.

Siamat D. 2005. Manajemen Lembaga Keuangan Edisi Kelima. Jakarta (ID): Lembaga Penerbit FE UI.

Wibowo ES, Syaichu M. 2013. Analisis Pengaruh Suku Bunga, Inflasi, CAR, BOPO, NPF Terhadap Profitabilitas Bank Syariah. Dipenogoro Journal of Management. 2(2):1-10.

[OJK] Otoritas Jasa Keuangan. 2016. Statistik Perbankan Syariah. [Internet]. [diunduh: 2016 April 10]. Tersedia pada: http://www.ojk.go.id

[BI] Bank Indonesia. 2016. Data Bi Rate 2011-2015. [Internet]. [diunduh: 2016 April 10]. Tersedia pada: http://www.bi.go.id

[BPS] Badan Pusat Statistik. 2016. Data Inflasi (Indeks Harga Konsumen) 2011-2015. [Internet]. [diunduh: 2016 April 10]. Tersedia pada: http://www.bps.go.id

[BI] Bank Indonesia. 2016. Surat Edaran Bank Indonesia No. 
9/29/DPbs tahun 2007.

[Internet]. [diunduh: 2016

April 23]. Tersedia pada:

http://www.bi.go.id

Dendawijaya L. 2005. Manajemen

Perbankan. Bogor (ID):

Ghalia Indonesia

Gujarati DN. 2006. Dasar-Dasar

Ekonometrika Edisi Ketiga jilid 1. Jakarta (ID). Erlangga

Harahap S. 2006 Analisis Kritis atas Laporan Keuangan. Jakarta (ID): Raja Grafindo Persada.

Ismail AK. 2011. Manajemen Perbankan: Dari Teori Menuju Aplikasi. Jakarta (ID): Kencana.

Rosly SA. 2005 Critical Issues on Islamic Banking and Financial Markets. Kuala Lumpur (MY): Danamas.

Purwanto TJ. 2011. Analisis Besarnya Pengaruh Pembiayaan, Financing to Deposit Ratio (FDR) dan Rasio Non Performing Financing (NPF) Terhadap Laba Bank Syariah (Studi Kasus PT. Bank Muamalat Indonesia, Tbk) [Skripsi]. Bogor (ID): Institut Pertanian Bogor. 